University of Nebraska - Lincoln

DigitalCommons@University of Nebraska - Lincoln

USDA National Wildlife Research Center - Staff Publications
U.S. Department of Agriculture: Animal and Plant Health Inspection Service

2018

\title{
Visual cues for woodpeckers: light reflectance of decayed wood varies by decay fungus
}

\author{
Sean T. O'Daniels \\ University of Missouri, odaniels.sean@gmail.com \\ Dylan C. Kesler \\ University of Missouri \\ Jeanne D. Mihail \\ University of Missouri \\ Elisabeth B. Webb \\ University of Missouri \\ Scott J. Werner \\ USDA/APHIS/Wildlife Services
}

Follow this and additional works at: https://digitalcommons.unl.edu/icwdm_usdanwrc

Part of the Life Sciences Commons

O'Daniels, Sean T.; Kesler, Dylan C.; Mihail, Jeanne D.; Webb, Elisabeth B.; and Werner, Scott J., "Visual cues for woodpeckers: light reflectance of decayed wood varies by decay fungus" (2018). USDA National Wildlife Research Center - Staff Publications. 2125.

https://digitalcommons.unl.edu/icwdm_usdanwrc/2125

This Article is brought to you for free and open access by the U.S. Department of Agriculture: Animal and Plant Health Inspection Service at DigitalCommons@University of Nebraska - Lincoln. It has been accepted for inclusion in USDA National Wildlife Research Center - Staff Publications by an authorized administrator of DigitalCommons@University of Nebraska - Lincoln. 


\title{
Visual cues for woodpeckers: light reflectance of decayed wood varies by decay fungus
}

\author{
Sean T. O’Daniels, ${ }^{1,2,7 *}$ Dylan C. Kesler, ${ }^{2,3}$ Jeanne D. Mihail, ${ }^{4}$ Elisabeth B. Webb, ${ }^{5}$ and \\ Scott J. Werner ${ }^{6}$
}

\begin{abstract}
The appearance of wood substrates is likely relevant to bird species with life histories that require regular interactions with wood for food and shelter. Woodpeckers detect decayed wood for cavity placement or foraging, and some species may be capable of detecting trees decayed by specific fungi; however, a mechanism allowing for such specificity remains unidentified. We hypothesized that decay fungi associated with woodpecker cavity sites alter the substrate reflectance in a species-specific manner that is visually discriminable by woodpeckers. We grew 10 species of wood decay fungi from pure cultures on sterile wood substrates of 3 tree species. We then measured the relative reflectance spectra of decayed and control wood wafers and compared them using the receptor noise-limited (RNL) color discrimination model. The RNL model has been used in studies of feather coloration, egg shells, flowers, and fruit to model how the colors of objects appear to birds. Our analyses indicated 6 of 10 decayed substrate/control comparisons were above the threshold of discrimination (i.e., indicating differences discriminable by avian viewers), and 12 of 13 decayed substrate comparisons were also above threshold for a hypothetical woodpecker. We conclude that woodpeckers should be capable of visually detecting decayed wood on trees where bark is absent, and they should also be able to detect visually species-specific differences in wood substrates decayed by fungi used in this study. Our results provide evidence for a visual mechanism by which woodpeckers could identify and select substrates decayed by specific fungi, which has implications for understanding ecologically important woodpecker-fungus interactions. Received 30 September 2016. Accepted 30 March 2017.
\end{abstract}

Key words: mutualisms, receptor noise-limited model, visual cues, wood decay fungi, woodpecker.

\section{Señales visuales para carpinteros: la reflectancia de luz de la madera degradada varía según el hongo degradador}

RESUMEN (Spanish) —El aspecto de los sustratos de madera posiblemente sea relevante para especies de aves que tienen historias de vida que dependen de interacciones regulares con la madera para alimentación y resguardo. Los pájaros carpinteros detectan la madera degradada para establecer sus cavidades o para forrajear, y algunas especies podrían ser capaces de detectar árboles que son degradadas por algún hongo en particular. Sin embargo, aún no se identifica un mecanismo que permita identificar tal especificidad. Nuestra hipótesis es que los hongos xilófagos asociados a sitios con cavidades para carpinteros alteran la reflectancia del sustrato en una manera específica a especie que es visualmente discernible para los carpinteros. Cultivamos 10 especies de hongos xilófagos a partir de cultivos puros en sustratos estériles de madera de tres especies de árboles. A continuación, medimos el espectro de reflectancia de la madera de la madera degradada y trozos de madera control, y las comparamos entre sí usando el modelo de discriminación de color del receptor de ruido limitado (RNL, por sus siglas en inglés). El modelo RNL ha sido utilizado en estudios de coloración de plumas, cascarón de huevo, flores y frutos para modelar cómo perciben las aves el color de los objetos. Nuestros análisis indican que 6 de 10 comparaciones sustrato/control estuvieron por encima del umbral de discriminación (e.g., indicando diferencias discernibles por observadores aviares) y que las comparaciones de 12 de los 13 sustratos degradados estuvieron por encima del umbral para un carpintero hipotético. Concluimos que los carpinteros deben ser capaces de detectar visualmente la madera degradada en árboles donde la corteza está ausente y también deben detectar visualmente diferencias específicas a especie en los sustratos de madera degradada por los hongos utilizados en este estudio. Nuestros resultados proveen evidencia de un mecanismo visual por medio del cual los pájaros carpinteros pueden identificar y seleccionar los sustratos degradados por hongos específicos, lo cual tiene implicaciones en nuestro entendimiento de las importantes interacciones entre carpinteros y hongos.

Palabras clave: hongos xilófagos o degradadores de madera, modelo receptor de ruido limitado, mutualismos, pájaros carpinteros, señales visuales.

\footnotetext{
${ }^{1}$ Missouri Cooperative Fish and Wildlife Research Unit, University of Missouri, Columbia, MO, USA.

${ }^{2}$ Department of Fisheries and Wildlife Sciences, University of Missouri, Columbia, MO, USA.

${ }^{3}$ Institute for Bird Populations, Point Reyes Station, CA, USA.

${ }^{4}$ Division of Plant Sciences, University of Missouri, Columbia, MO, USA.

${ }^{5}$ US Geological Survey, Missouri Cooperative Fish and Wildlife Research Unit, University of Missouri, Columbia, MO, USA.

${ }^{6}$ USDA/APHIS/Wildlife Services, National Wildlife Research Center, Ft. Collins, CO, USA.

${ }^{7}$ Current address: 5632 Nieman Rd., Shawnee, KS, USA.

Note: Secondary authors listed alphabetically.

* Corresponding author: odaniels.sean@gmail.com
} 
That color signals are important to birds has been evident since at least the days of Aristotle (350 BCE), although our understanding of those signals has historically been interpreted through the eyes of humans. Avian visual ecology studies have become prevalent in recent decades, driven both by the advent of new technologies and an increased understanding that most organisms visualize their surroundings differently than humans (Kemp et al. 2015). To determine ecologically relevant information from studies of signals (color or otherwise), a signal should be viewed and analyzed from the perspective of the intended signal receiver (Hart 2001). For this, knowledge of the sensory capabilities of that intended receiver, or potential eavesdroppers, is needed.

Diurnal birds possess tetrachromatic vision due to the presence of 4 types of single cone cells (short-wave-sensitive 1, short-wave-sensitive 2, medium-wave-sensitive, and long-wave-sensitive; SWS1, SWS2, MWS, LWS, respectively) within the retina and a wavelength sensitivity range from 300 to $700 \mathrm{~nm}$ (Eaton 2005, Renoult et al. 2010). Avian visual sensitivity includes the near ultraviolet (UV; 300-400 nm) due to the presence of the SWS1 cone. The wavelength sensitivities of the avian LWS, MWS, and SWS2 cones are quite constant (Endler and Mielke 2005, Renoult et al. 2010); however, the SWS1 wavelength of maximum absorbance $\left(\lambda_{\max }\right)$ is variable, creating a dichotomous visual system within diurnal avifauna (Ödeen and Håstad 2003, Renoult et al. 2010). The ultraviolet sensitive (UVS) species exhibit an SWS1 $\lambda_{\max }$ of $355-373 \mathrm{~nm}$, whereas the violet sensitive (VS) species exhibit an SWS1 $\lambda_{\max }$ of 402-426 nm (Hart and Hunt 2007). The UVS system is found in the Paleognathae, Passeriformes (Passerida only, not Tyrannida or Corvida), Psittaciformes, and Laridae, with all other diurnal species currently presumed to have a VS system (Ödeen et al. 2011). Behavioral studies with VS species have shown that regardless of the SWS1 $\lambda_{\max }, \mathrm{UV}$ sensitivity may extend to at least $360 \mathrm{~nm}$ (Parrish et al. 1981, 1984; Blackwell et al. 2012).

Typically, $\lambda_{\max }$ values are measured directly by microspectrophotometry (MSP) or estimated from total DNA (Ödeen and Håstad 2003). Such data then can be incorporated into visual models to estimate the saliency of particular wavelengths or the discriminability of colors (e.g., Vorobyev and Osorio 1998, Endler and Mielke 2005). Retinal physiology data (e.g., MSP) are available for few species, and consequently MSP data from one species are often used to represent visual sensitivity in other species presumed to have similar visual systems (e.g., Eaton and Lanyon 2003). Based on our contemporary understandings of avian visual physiology, this approach is not necessarily unwarranted (but see Renoult et al. 2010) and has been acknowledged as a valuable first step for visual ecology studies (Kemp et al. 2015).

The receptor noise-limited (RNL) color discrimination model of Vorobyev and Osorio (1998) has been widely used in studies of feather coloration (e.g., Vorobyev et al. 1998, Eaton and Lanyon 2003, Eaton 2005, Burns and Shultz 2012). The RNL model calculates the difference between points (reflectance spectra; $\Delta \mathrm{S}$ ) within a theoretical color space and can be applied to di-, tri-, and tetrachromatic visual systems (Vorobyev and Osorio 1998). The model assumes that (a) discrimination of colors within the color space is limited by noise originating in the receptors, and (b) no visual signal occurs when the stimulus and background differ only in intensity (Eaton 2005). The RNL model requires an estimate of the noise inherent within the system of interest as well as information on the spectral sensitivities $(\lambda \max )$ for, and relative numbers of, photoreceptor types to predict discrimination between pairs of reflectance spectra.

The RNL model also has been used in discrimination studies of objects encountered by birds, such as egg shells (Igic et al. 2012), flowers (Herrera et al. 2008), and fruit (Schaefer et al. 2007). Reflectance spectra of wood substrates have been incorporated into some previous studies as background spectra (e.g., Eaton 2005), but no studies have specifically examined whether birds can discriminate between spectra of different wood substrates, decayed wood, or fungi. The visual appearance of wood substrates is likely relevant to at least some primary cavity excavators with life histories that require regular interactions with them for food and shelter.

Woodpeckers (Piciformes: Picidae: Picinae, Leach 1820) are an ecologically important group globally distributed across forest and woodland systems, except for Australia and some islands of Oceania. As primary cavity excavators, woodpeckers are a foundational link to nest web communities (Martin and Eadie 1999) because 
they excavate cavity resources that dozens of other vertebrate species also use (Aubry and Raley 2002, Arnett et al. 2010). Woodpeckers also facilitate the breakdown of dead trees, fallen logs, and coarse woody debris by creating openings for moisture, fungi, and other decomposition agents (Aubry and Raley 2002).

Woodpeckers are known to transport fungal material on their bills and feathers (Farris et al. 2004), and they influence the community of decay fungi at cavity locations (Jusino et al. 2015, 2016). Nest and roost cavities are typically excavated in standing dead timber, but some species use living trees (Jackson and Jackson 2004). Cavity placements of widely distributed woodpecker species are necessarily plastic in terms of height on tree, orientation on tree or limb, diameter of tree or limb, tree species, canopy cover, surrounding vegetation, and distance from edge (Winternitz and Cahn 1983, Aubry and Raley 2002, Jackson and Jackson 2004).

By contrast, cavity placement appears relatively uniform with regard to the condition of the wood substrate selected (Bednarz et al. 2004). Several woodpecker species select wood substrates experiencing fungal deterioration for both nest and roost cavities, usually by a member of the Polyporaceae (Basidiomycota) heart rot fungi (reviewed in Jackson and Jackson 2004, Zahner et al. 2012). Past work has suggested that at least 2 species of woodpeckers may have a preference for excavating cavities in substrates infected by particular species of heart rot fungus, including the endangered Red-cockaded Woodpecker (Leuconotopicus borealis) with red heart fungus (Porodaedalea pini; Steirly 1957, Jackson 1977, Conner and Locke 1982) and the Yellow-bellied Sapsucker (Sphyrapicus varius) with aspen heart rot (Phellinus tremulae syn. Phellinus igniarius var. populinus; Shigo and Kilham 1968, Kilham 1971). Recent molecular studies indicate, however, that woodpecker-fungi interactions should consider the community of decay fungi within cavity trees rather than focus on one particular decay species (Jusino et al. 2015, 2016).

Specific to the Red-cockaded Woodpecker, the 'bird facilitated hypothesis' (Jusino et al. 2015) holds that this species vectors decay fungi to new locations, a hypothesis supported by recent experimental evidence (Jusino et al. 2016). The 'tree selection hypothesis' (Jusino et al. 2015) asserts that the Red-cockaded Woodpecker selects trees already infected with $P$. pini for cavity placements, a historically accepted theory (Jusino et al. 2016), although no underlying mechanism or cue for such selection has been identified.

Evidence of deterioration by heart rots often is not obvious to human observers (Jackson and Jackson 2004), and the use of 'conks' (fruiting bodies of Polyporaceae) by woodpeckers as visual landmarks has been discounted for some species (Conner et al. 1976, Rudolph et al. 1995, Huss et al. 2002). Differences in resonance between decayed and sound wood have been suggested as one method by which woodpeckers may detect the presence of heart rots (Conner et al. 1976, Rudolph et al. 1995, Zahner et al. 2012). This hypothesis remains untested, however, and selection of trees infected by a specific decay fungus or fungal community seems unlikely by resonance alone. At the broadest scale, woodpeckers likely use the visual appearance of decaying trees to identify potential cavity trees (i.e., decay classes; Blanc and Martin 2012). Woodpeckers may also use visual cues to select excavation sites on suitable trees, particularly in areas where bark is absent. Reflectance spectra of decayed wood differ from those of sound wood, and different decay organisms impart varying substrate reflectance spectra (Klapstein et al. 1989).

We hypothesized that decay fungi associated with woodpecker cavity sites alter substrate reflectance in a species-specific manner that is visually discriminable by woodpeckers. We used the RNL model to assess whether reflectance spectra of decayed substrates could be discriminated by a hypothetical woodpecker based on the fungi responsible for the decay. We predicted that all decayed substrates would exhibit reflectance spectra different from control substrates and that substrates produced by decay organisms associated with woodpecker cavities would differ from most other decayed substrates.

In addition to their ecological importance, woodpeckers also can cause significant damage when excavating within anthropogenic structures (Harness and Walters 2004), and woodpecker damage to wood siding and trim in particular is often associated with areas of decay (STO, pers. obs.). Therefore, we were interested in whether reflectance spectra of substrates decayed by fungi associated with anthropogenic structures (i.e., in- 
Table 1. List of decay fungi used in this study. Pure cultures of each were obtained from the Center for Forest Mycology, Research Culture Collection, US Forest Service, Madison, WI.

\begin{tabular}{|c|c|c|c|c|}
\hline Decay fungi (strain ID) & Wood substrate & Relevance & Woodpecker species & Reference \\
\hline $\begin{array}{l}\text { Phellinus igniarius } \\
\text { (HHB-15085-T) }\end{array}$ & Quaking aspen & $\begin{array}{l}\text { Woodpecker, heart } \\
\text { rot }\end{array}$ & $\begin{array}{l}\text { Colaptes auratus, } \\
\text { Picoides spp., } \\
\text { Sphyrapicus spp. }\end{array}$ & $\begin{array}{l}\text { Winternitz and Cahn } \\
\text { (1983) }\end{array}$ \\
\hline $\begin{array}{l}\text { Phellinus tremulae (FP- } \\
\text { 140054-T) }\end{array}$ & Quaking aspen & $\begin{array}{l}\text { Woodpecker, heart } \\
\text { rot }\end{array}$ & $\begin{array}{l}\text { Sphyrapicus varius } \\
\text { (Yellow-bellied } \\
\text { Sapsucker) }\end{array}$ & $\begin{array}{l}\text { Shigo and Kilham } \\
(1968) \\
\text { Jackson and Jackson } \\
(2004)\end{array}$ \\
\hline $\begin{array}{l}\text { Bjerkandera adusta (L- } \\
\text { 15463-Sp) }\end{array}$ & N. red oak & In-service & & \\
\hline $\begin{array}{l}\text { Fomes fomentarius (TJV- } \\
\text { 93-7-T) }\end{array}$ & N. red oak & Heart rot & & \\
\hline $\begin{array}{l}\text { Spongipellis pachyodon } \\
\text { (RLG-14764-SP) }\end{array}$ & N. red oak & $\begin{array}{l}\text { Woodpecker, heart } \\
\text { rot }\end{array}$ & $\begin{array}{l}\text { Dryocopus pileatus } \\
\quad \text { (Pileated) }\end{array}$ & Conner et al. (1976) \\
\hline $\begin{array}{l}\text { Trametes versicolor } \\
\text { (Mad-697) }\end{array}$ & N. red oak & In-service & & \\
\hline $\begin{array}{l}\text { Coniophora puteana } \\
\text { (Mad-515) }\end{array}$ & Red pine & $\begin{array}{l}\text { Woodpecker, heart } \\
\text { rot, in-service }\end{array}$ & Not identified & Parks et al. (1996) \\
\hline $\begin{array}{l}\text { Fomitopsis pinicola (MJ- } \\
\text { 50101) }\end{array}$ & Red pine & $\begin{array}{l}\text { Woodpecker, heart } \\
\text { rot }\end{array}$ & Picoides villosus (Hairy) & Huss et al. (2002) \\
\hline $\begin{array}{l}\text { Gleophyllum trabeum } \\
\text { (Mad-617-R) }\end{array}$ & Red pine & In-service & & \\
\hline $\begin{array}{l}\text { Porodaedalea pini (AZ- } \\
\text { 10-T) }\end{array}$ & Red pine & $\begin{array}{l}\text { Woodpecker, heart } \\
\text { rot }\end{array}$ & $\begin{array}{l}\text { Leuconotopicus borealis } \\
\text { (Red-cockaded) }\end{array}$ & Steirly (1957) \\
\hline
\end{tabular}

service decay fungi) were similar to substrates decayed by cavity-associated fungi such that those substrates could be mistaken for substrates decayed by cavity-associated fungi. We predicted that some in-service decay fungi would produce substrates not discriminable from substrates produced by some of the cavity-associated fungi.

\section{Methods}

\section{Wood substrates}

To examine differences in light reflected from decayed and sound wood, we selected 10 decay organisms (i.e., treatments) and 3 wood substrates (Table 1). Decay organisms were selected because of their association with woodpecker cavities in the literature or their association with anthropogenic structures (i.e., in-service decay fungi). Wood substrates used in this study were $20 \times 20$ $\times 3 \mathrm{~mm}$ wafers of quaking aspen (Populus tremuloides), northern red oak (Quercus rubra), and red pine (Pinus resinosa). All wafers were from the same individual trees, cut perpendicular to the transverse plane (across the grain) to facilitate fungal colonization.
All wafers were autoclaved in broths of either $2 \%$ malt extract (2M; red oak, red pine) or $0.5 \%$ potato dextrose ( $\mathrm{PD}$; aspen). Sterile wafers were transferred to petri dishes (plates) containing either $2 \mathrm{M}$ agar or PD agar (1 per plate). Plates were sealed with Parafilm to prevent desiccation and allow gas exchange and placed in ambient indoor dark conditions to monitor for contamination. After 7 $\mathrm{d}$, plates were assigned randomly to either control or treatment groups. Each treatment plate was inoculated with a single decay organism by agar block transfer from pure cultures (Center for Forest Mycology Research Culture Collection, US Forest Service, Madison, WI). Control plates were unmanipulated. We created 6 replicate plates (wafers) of each decay organism and 5 replicate control wafers of each tree species. After inoculation, plates were resealed and returned to dark storage for 5 months.

We were interested in measuring the reflectance of the underlying wood substrates after the decay process rather than the reflectance of fungal mycelium. Therefore, after $\sim 5$ months, treatment wafers were extracted from plates and all fungal mycelia were manually scraped from the wafer surfaces. All wafers were then placed on paper 
towels and allowed to desiccate for at least $72 \mathrm{~h}$ before reflectance measurements were collected. Red pine wafers decayed by $P$. pini were created in 2014 along with a set of control red pine wafers. All other wafers were created in 2015 with an additional set of red pine control wafers.

The surface reflectance of each treatment and control wafer relative to a white standard was measured using an Ocean Optics USB2000+ microspectrophotometer calibrated for 200-850 $\mathrm{nm}$ with a QR400-7-UV-BX reflectance probe and a PX-2 pulsed xenon light source (Ocean Optics; Dunedin, FL, USA). The probe was calibrated against white (WS-1 Spectralon) and black (lightless) standards and recalibrated between each set (i.e., 5 or 6 ) of wafers. Reflectance measurements were recorded at 6 points on each wafer and averaged to create a mean reflectance spectrum for each wafer. A modified black rubber stopper was used to hold the probe at a fixed distance $(5 \mathrm{~mm})$ and angle $\left(90^{\circ}\right)$ and to eliminate ambient light during reflectance measurements.

\section{Visual model}

The RNL model was implemented through the pavo package 0.5-4 (Maia et al. 2013) within the $\mathrm{R}$ environment 3.2.3 (R Core Team 2015). Specific details of the model can be found elsewhere (Vorobyev et al. 1998), but the Weber fraction, an estimate of the noise within each receptor type, is a limiting function of color discrimination (Vorobyev and Osorio 1998). The RNL model requires an input for the Weber fraction of the LWS cone only, with noise in the other cone types calculated based on their relative abundances. We used a relative cone abundance ratio of 1:2:2:4 (SWS1:SWS2:MWS:LWS) in our models. This ratio is found in the Red-billed Leiothrix (Leothrix lutea; Maier and Bowmaker 1993) and has been used in at least 2 previous studies utilizing the RNL model (Vorobyev et al. 1998, Herrera et al. 2008). Although cone densities likely vary between species, evidence indicates that such differences may be related to visual ecology (Hart 2001 and references therein). Because the Red-billed Leiothrix is native to forest and woodland habitats from southern China to the western Himalayas (Amano and Eguchi 2002), we assumed this cone density ratio for woodpecker species.
Estimates of Weber fractions are available for few bird species and likely vary by species (Vorobyev 2003). Published values for the Weber fraction of avian LWS mechanisms range from 0.06 for domestic Red Junglefowl (Gallus gallus; Olssen et al. 2015) to 0.1 for the Red-billed Leiothrix (Schaeffer et al. 2007). Behavioral data suggest that an LWS Weber fraction close to that of Red Junglefowl may be appropriate for Pileated Woodpeckers (Dryocopus pileatus; O'Daniels et al. 2017). Because most published studies based on the RNL model have used an LWS Weber fraction of 0.1 , we present modeled data for 0.06 and 0.1 LWS Weber fractions (0.1 LWS data in Supplemental Materials).

To our knowledge, no MSP data have been published for any woodpecker species, but Ödeen and Håstad (2003) estimated an SWS1 $\lambda_{\max }$ of 405 $\mathrm{nm}$ for the Great Spotted Woodpecker (Dendrocopos major); therefore, we modeled color discrimination for a hypothetical woodpecker based on the receptor quantum catches for the average VS bird under woodland shade irradiance (Endler 1993). The average VS model includes average absorbance values for the 4 cone receptor types $(\mathrm{SWS} 1=412$ $\mathrm{nm} ; \mathrm{SWS} 2=452 \mathrm{~nm} ; \mathrm{MWS}=459 \mathrm{~nm} ; \mathrm{LWS}=565$ $\mathrm{nm}$ ) with associated oil droplets (short, $\mathrm{S}=459$; medium, $\mathrm{M}=525$; long, $\mathrm{L}=588$ ) and optical media (362 nm; Endler and Mielke 2005). Woodland shade irradiance also describes the light environment of coniferous forests (Endler 1993), which along with woodlands are typical woodpecker habitats. Additionally, even the densest temperate deciduous forests experience prolonged periods with little to no leaf canopy precisely when many woodpeckers excavate cavities.

We compared the mean reflectance spectrum of each wafer (smoothing parameter $=0.2$ ) to all other wafers of the same substrate (aspen, oak, or pine) using the RNL model to generate mean $\Delta \mathrm{S}$ values with $95 \%$ confidence intervals from all possible pair-wise comparisons, both within (e.g., all control aspen wafers) and between (e.g., $P$. igniarius vs. P. tremulae) wafer types. The units of $\Delta \mathrm{S}$ are just noticeable differences (JNDs), with $\Delta \mathrm{S}$ $>1.0 \mathrm{JND}$ considered discriminable (Vorobyev et al. 1998). We used 1-sample, 2-tailed $t$-tests to test for $\Delta \mathrm{S}$ values different from $1.0(\alpha<0.05$; Igic et al. 2012) and applied Bonferroni corrections to account for multiple pair-wise comparisons. Incorporating different background spectra into the 


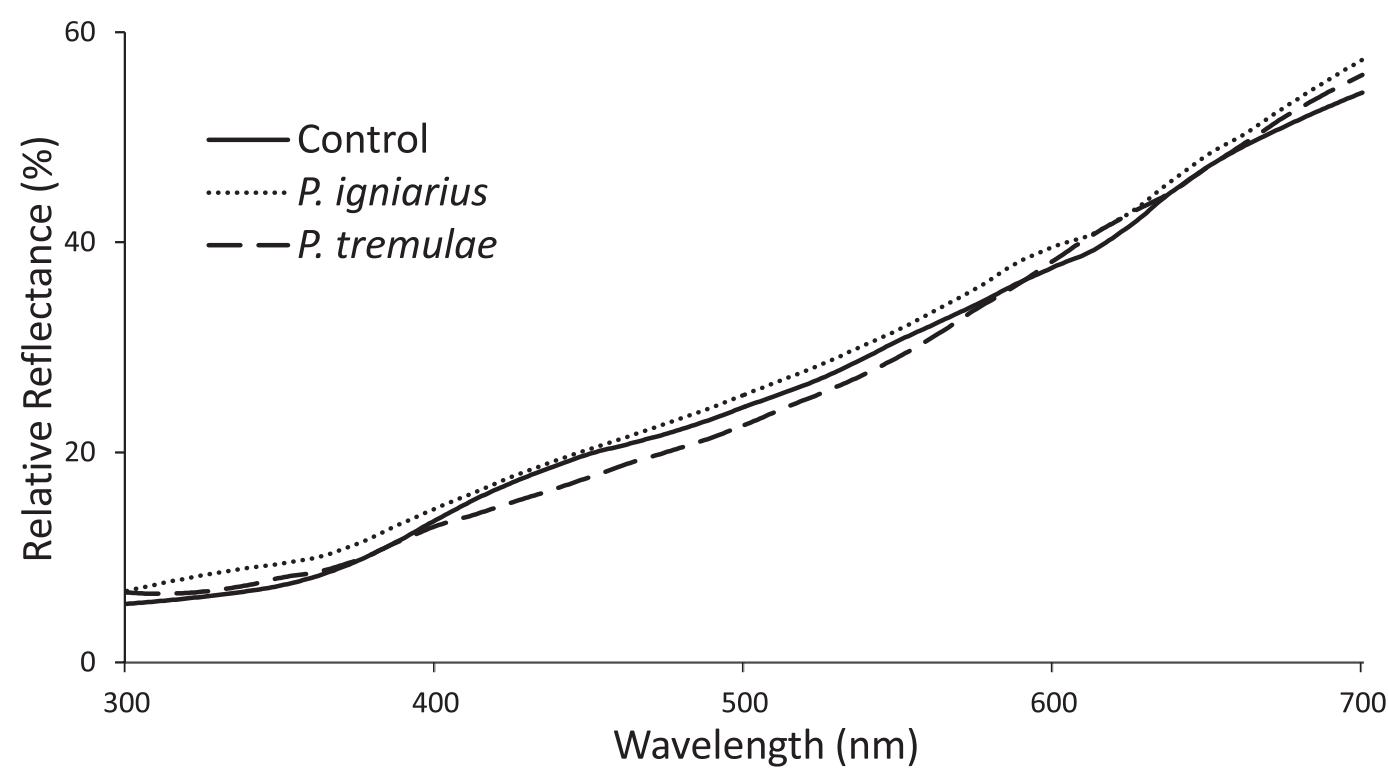

Figure 1. Mean reflectance spectra of decayed and control quaking aspen (Populus tremuloides) substrates over 300-700 nm created in 2015. Error bars not shown for clarity. Decayed substrates were decayed by one decay fungus (Phellinus igniarius or P. tremulae).

model did not produce different results, similar to findings reported by others (e.g., Eaton 2005).

\section{Results}

Mean reflectance spectra of aspen substrates (Fig. 1) were perceptually different in only 2 comparisons according to the RNL model. With an

Table 2. Receptor noise-limited model results of quaking aspen (Populus tremuloides) substrates; Weber fraction = 0.06. Mean $\Delta \mathrm{S}(95 \% \mathrm{CI}) ; n=$ number of pairwise comparisons used to generate mean $\Delta \mathrm{S}$. Bold values indicate $\Delta \mathrm{S}>1$ JND (Bonferroni-adjusted $P<0.05$ ).

\begin{tabular}{|c|c|c|c|}
\hline \multirow[b]{2}{*}{$\begin{array}{l}\text { Reference } \\
\text { substrate }\end{array}$} & \multicolumn{3}{|c|}{ Comparison substrate } \\
\hline & Aspen & $\begin{array}{l}\text { Phellinus } \\
\text { igniarius }\end{array}$ & $\begin{array}{l}\text { Phellinus } \\
\text { tremulae }\end{array}$ \\
\hline Aspen & $\begin{array}{c}1.7(0.8-2.5) \\
P=0.71 \\
n=10\end{array}$ & & \\
\hline $\begin{array}{l}\text { Phellinus } \\
\quad \text { igniarius }\end{array}$ & $\begin{array}{c}1.4(0.9-1.9) \\
P=0.73 \\
n=25\end{array}$ & $\begin{array}{c}1.6(0.6-2.5) \\
P=1 \\
n=10\end{array}$ & \\
\hline $\begin{array}{l}\text { Phellinus } \\
\text { tremulae }\end{array}$ & $\begin{array}{c}1.5(\mathbf{1 . 3}-\mathbf{1 . 8}) \\
P<0.001 \\
n=30\end{array}$ & $\begin{array}{c}1.6(1.4-1.9) \\
P<0.001 \\
n=30\end{array}$ & $\begin{array}{c}1.0(0.7-1.3) \\
P=1 \\
n=15\end{array}$ \\
\hline
\end{tabular}

LWS Weber fraction of 0.06 , aspen substrates decayed by $P$. tremulae were above threshold when compared with control substrates $(\Delta \mathrm{S}=1.5$, $P<0.001)$ and substrates decayed by $P$. igniarius $(\Delta \mathrm{S}=1.6, P<0.001)$. P. igniarius substrates were not above threshold compared with controls (Table 2). No aspen substrate comparisons exceeded the threshold of discrimination with an LWS Weber fraction of 0.1 (Supplemental Table S1). Assuming the average VS system is representative of woodpecker vision, these results support the hypothesis that woodpeckers could visually detect aspen substrates decayed by $P$. tremulae.

Mean reflectance spectra of decayed red oak substrates (Fig. 2) were perceptually different in a majority (55\%) of comparisons according to the RNL model. With an LWS Weber fraction of $0.06,2$ of 4 decayed substrates were above threshold compared with control substrates: Fomes fomentarius $(\Delta \mathrm{S}=2.0, P<0.001)$ and Spongipellis pachyodon $(\Delta \mathrm{S}=2.5, P<0.001)$, and 5 of 6 comparisons of decayed red oak substrates were also above threshold (Table 3). When an LWS Weber fraction of 0.1 was considered, only $S$. pachyodon was above threshold compared with controls $(\Delta \mathrm{S}=1.5, P<$ 0.001 ), and 3 of 6 comparisons of decayed 


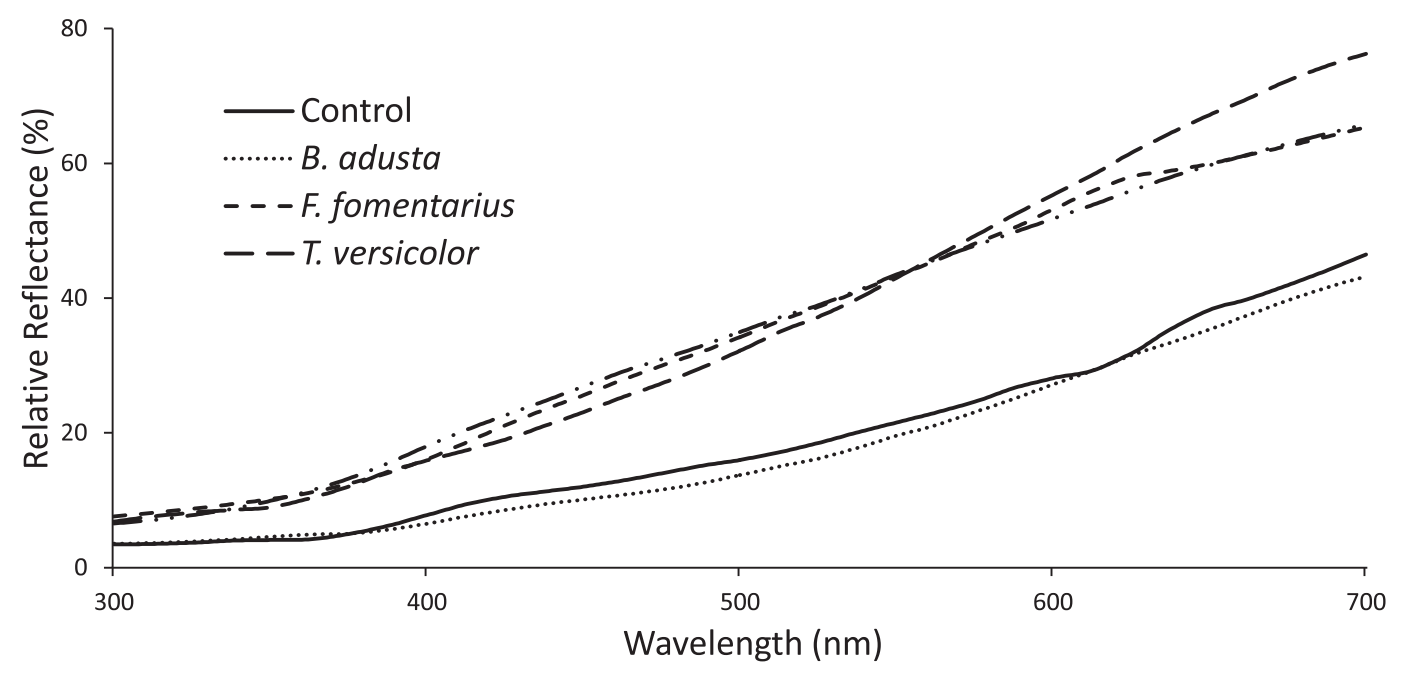

Figure 2. Mean reflectance spectra of decayed and control northern red oak (Quercus rubra) substrates over 300-700 nm created in 2015. Error bars not shown for clarity. Decayed substrates were decayed by one decay fungus (Bjerkandera adusta, Fomes fomentarius, Spongipellis pachyodon, or Trametes versicolor).

substrates were above threshold. (Supplemental Table S2). These results support the hypothesis that woodpeckers could visually detect northern red oak substrates decayed by S. pachyodon and several other decay fungi.

Mean reflectance spectra of decayed red pine substrates (Fig. 3) were perceptually different in most (75\%) comparisons according to the RNL model. With an LWS Weber fraction of $0.06,3$ of
4 decayed pine substrates were above threshold compared with control substrates: Coniophora puteana $(\Delta \mathrm{S}=1.3, P<0.001)$, Gleophyllum trabeum $(\Delta \mathrm{S}=2.8, P<0.001), P$. pini $(\Delta \mathrm{S}=3.1$, $P<0.001)$. All 6 comparisons of decayed red pine substrates were also above threshold (Table 4). With an LWS Weber fraction of $0.1,2$ of 4 substrates were above threshold compared with controls, and 4 of 6 comparisons of decayed

Table 3. Receptor noise-limited model results of northern red oak (Quercus rubra) substrates; Weber fraction $=0.06$. Mean $\Delta \mathrm{S}(95 \% \mathrm{CI}) ; n=$ number of pairwise comparisons used to generate mean $\Delta \mathrm{S}$. Bold values indicate $\Delta \mathrm{S}>1 \mathrm{JND}$ (Bonferroni-adjusted $P<0.05$ ), ${ }^{\ddagger}$ denotes values not significant after Bonferroni correction.

\begin{tabular}{|c|c|c|c|c|c|}
\hline \multirow[b]{2}{*}{ Reference substrate } & \multicolumn{5}{|c|}{ Comparison substrate } \\
\hline & Red oak & Bjerkandera adusta & Fomes fomentarius & Spongipellis pachyodon & Trametes versicolor \\
\hline Red oak & $\begin{array}{c}0.7(0.4-1.0) \\
P=1 \\
n=10\end{array}$ & & & & \\
\hline Bjerkandera adusta & $\begin{array}{c}1.5(1.1-1.9)^{+} \\
P=0.14 \\
n=25\end{array}$ & $\begin{array}{c}1.4(1.0-1.9) \\
P=1 \\
n=10\end{array}$ & & & \\
\hline Fomes fomentarius & $\begin{array}{c}2.0(\mathbf{1 . 7}-\mathbf{2 . 3}) \\
P<0.001 \\
n=25\end{array}$ & $\begin{array}{c}3.3(\mathbf{2 . 8}-\mathbf{3 . 8}) \\
P<0.001 \\
n=25\end{array}$ & $\begin{array}{c}1.5(0.8-2.3) \\
P=1 \\
n=10\end{array}$ & & \\
\hline Spongipellis pachyodon & $\begin{array}{c}2.5(\mathbf{2 . 3}-\mathbf{2 . 8}) \\
P<0.001 \\
n=30\end{array}$ & $\begin{array}{c}4.0(3.6-4.3) \\
P<0.001 \\
n=30\end{array}$ & $\begin{array}{c}1.2(0.8-1.6) \\
P=1 \\
n=30\end{array}$ & $\begin{array}{c}0.7(0.5-0.9)^{*} \\
P=0.25 \\
n=15\end{array}$ & \\
\hline Trametes versicolor & $\begin{array}{c}0.9(0.7-1.0) \\
P=0.96 \\
n=25\end{array}$ & $\begin{array}{c}1.9(\mathbf{1 . 5}-\mathbf{2 . 3}) \\
P<0.001 \\
n=25\end{array}$ & $\begin{array}{c}\mathbf{1 . 8}(\mathbf{1 . 5}-\mathbf{2 . 1}) \\
P<0.001 \\
n=25\end{array}$ & $\begin{array}{c}2.3(\mathbf{2 . 0}-\mathbf{2 . 6 )} \\
P<0.001 \\
n=30\end{array}$ & $\begin{array}{c}1.0(0.8-1.3) \\
P=1 \\
n=10\end{array}$ \\
\hline
\end{tabular}




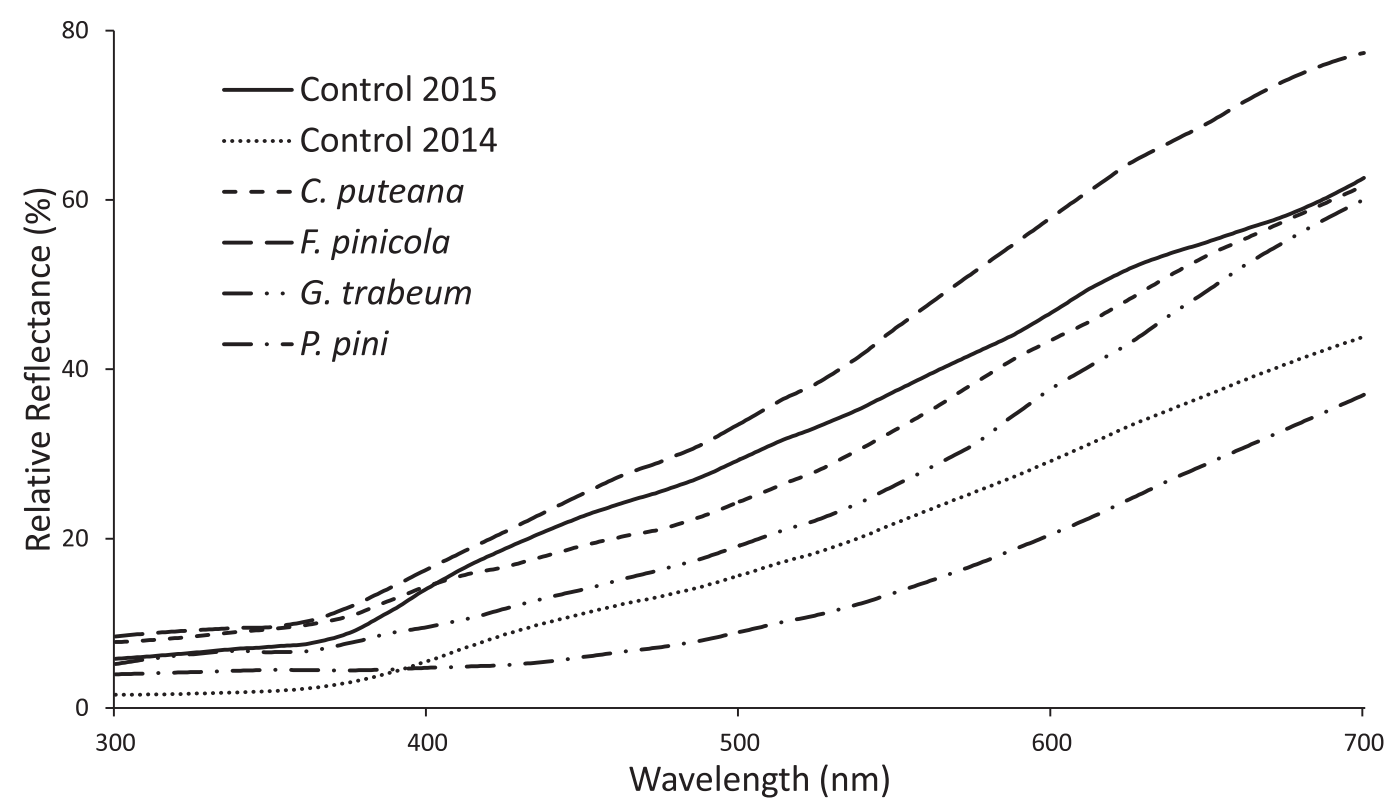

Figure 3. Mean reflectance spectra of decayed and control red pine (Pinus resinosa) substrates over 300-700 nm. Control 2014 and P. pini wafers were created in 2014; all other wafers were created in 2015. Error bars not shown for clarity. Decayed substrates were decayed by one decay fungus (Coniophora puteana, Fomitopsis pinicola, Geophyllum trabeum, or Porodadalea pini).

substrates were also above threshold (Supplemental Table S3). These results support the hypothesis that woodpeckers could visually detect red pine substrates decayed by $P$. pini and several other decay fungi.

\section{Discussion}

If the average VS system is appropriate for woodpecker vision, our results indicate that in many cases decayed and sound wood substrates

Table 4. Receptor noise-limited model results of red pine (Pinus resinosa) substrates; Weber fraction $=0.06$. Mean $\Delta \mathrm{S}(95 \%$ $\mathrm{CI}$ ); $n=$ number of pairwise comparisons used to generate mean $\Delta \mathrm{S}$. Bold values indicate $\Delta \mathrm{S}>1 \mathrm{JND}$ (Bonferroni-adjusted $P$ $<0.05$ ); * denotes $\Delta \mathrm{S}<1 \mathrm{JND}$ (Bonferroni-adjusted $P<0.05$ ); ${ }^{*}$ denotes values not significant after Bonferroni correction.

\begin{tabular}{|c|c|c|c|c|c|}
\hline \multirow[b]{2}{*}{ Reference substrate } & \multicolumn{5}{|c|}{ Comparison substrate } \\
\hline & Red pine & Coniophora puteana & Fomitopsis pinicola & Gleophyllum trabeum & Porodaedalea pini \\
\hline Red pine & $\begin{array}{c}0.4(0.3-0.5)^{*} \\
P<0.001 \\
n=10\end{array}$ & & & & \\
\hline Coniophora puteana & $\begin{array}{c}\mathbf{1 . 3}(\mathbf{1 . 2}-\mathbf{1 . 3}) \\
P<0.001 \\
n=30\end{array}$ & $\begin{array}{c}0.4(0.3-0.5)^{*} \\
P<0.001 \\
n=15\end{array}$ & & & \\
\hline Fomitopsis pinicola & $\begin{array}{c}1.4(1.0-1.9)^{*} \\
P=0.51 \\
n=30\end{array}$ & $\begin{array}{c}1.6(\mathbf{1 . 4 - 1 . 7 )} \\
P<0.001 \\
n=36\end{array}$ & $\begin{array}{c}1.8(1.2-2.4)^{*} \\
P=0.12 \\
n=15\end{array}$ & & \\
\hline Gleophyllum trabeum & $\begin{array}{c}2.8(\mathbf{2 . 6}-\mathbf{3 . 0}) \\
P<0.001 \\
n=30\end{array}$ & $\begin{array}{c}2.0(\mathbf{1 . 9}-\mathbf{2 . 2}) \\
P<0.001 \\
n=36\end{array}$ & $\begin{array}{c}1.9(\mathbf{1 . 5}-\mathbf{2 . 3}) \\
P<0.001 \\
n=36\end{array}$ & $\begin{array}{c}0.9(0.7-1.1) \\
P=1 \\
n=15\end{array}$ & \\
\hline Porodaedalea pini & $\begin{array}{c}\mathbf{3 . 1}(\mathbf{2 . 8}-\mathbf{3 . 3}) \\
P<0.001 \\
n=36\end{array}$ & $\begin{array}{c}4.2(3.9-4.5) \\
P<0.001 \\
n=36\end{array}$ & $\begin{array}{c}3.9(3.4-4.4) \\
P<0.001 \\
n=36\end{array}$ & $\begin{array}{c}2.4(\mathbf{2 . 1}-\mathbf{2 . 7 )} \\
P<0.001 \\
n=36\end{array}$ & $\begin{array}{c}1.4(1.1-1.8) \\
P=0.24 \\
n=15\end{array}$ \\
\hline
\end{tabular}


will appear visually different to woodpeckers based on the species of fungi responsible for the decay. Red pine substrates decayed by P. pini and northern red oak substrates decayed by $S$. pachyodon were above the threshold of discrimination compared with most other substrates in our study, even when more conservative visual model parameters were considered. These results are relevant because both fungi are known to be associated with woodpecker cavities (Jackson and Jackson 2004), and woodpecker detection by the use of external basidiocarps (conks) is unlikely for these 2 fungi (Connor et al. 1976, Rudolph et al. 1995). Additionally, Pileated Woodpeckers successfully discriminated between P. pini wafers and control red pine wafers in captive behavioral trials $(\Delta \mathrm{S}=2.4$, average VS model; O'Daniels et al. 2017).

The results for other woodpecker-associated decay fungi were more equivocal. Aspen substrates decayed by P. igniarius were not different from control substrates, regardless of model parameters, a result that did not meet our predictions. We expected $P$. igniarius substrates to be discriminable from controls based on published associations with woodpecker cavity locations; however, P. tremulae substrates were above threshold when compared with both control and P. igniarius substrates with an LWS Weber fraction of 0.06. P. tremulae was somewhat recently separated from $P$. igniarius (Jackson and Jackson 2004). Some previous researchers (Shigo and Kilham 1968, Kilham 1971) identified $P$. igniarius var. populinus (syn. P. tremulae) as the decay fungus isolated from woodpecker cavities in aspen trees, but others only identified the fungus as P. igniarius (Winternitz and Cahn 1983). $P$. igniarius does infect aspen, but aspen cavity trees identified by Winternitz and Kahn (1983) were possibly decayed by $P$. tremulae rather than $P$. igniarius. These fungi produce discriminable substrates under certain conditions, which may also be an important finding if future research demonstrates that $P$. tremulae is preferred by sapsuckers or other woodpeckers over $P$. igniarius when selecting cavity sites in aspen trees.

Fomitopsis pinicola has been associated with woodpecker cavities located in fir (Abies spp.), hemlock (Tsuga spp.), and spruce (Picea spp.) trees in Northwestern North America (Huss et al. 2002), and we expected it to produce multiple above-threshold substrate comparisons, similar to the results with $P$. pini and $S$. pachyodon. After Bonferroni corrections with an LWS Weber fraction of $0.06, F$. pinicola substrates were not different from control red pine (a possible Type II error; Nakagawa 2004) but were above threshold compared with the other 3 fungi. With an LWS Weber fraction of 0.1 , however, $F$. pinicola was discriminable only from $P$. pini. Our experimental substrates were from red pine, a species that does not occur in Northwestern North America. Other tree species decayed by $F$. pinicola (i.e., fir, hemlock, spruce) may have a different appearance and may produce more above-threshold (i.e., discriminable) substrate comparisons. This logic applies to any combination of tree species and decay fungus.

Comparisons of substrates decayed by inservice fungi (B. adusta, C. puteana, G. trabeum, and $T$. versicolor) and those decayed by woodpecker-associated fungi produced above threshold values in every case with an LWS Weber fraction of 0.06 . Only F. pinicola vs. G. trabeum and F. fomentarius vs. T. versicolor were not above the threshold with an LWS Weber fraction of 0.1, and while $F$. fomentarius is a heart rot, it is not currently known to be associated with woodpecker cavities. Our results do not support the idea that these in-service decay fungi could be visually mistaken for a 'preferred' decay fungus when they occur on anthropogenic structures, but by examining only 10 of $>10,000$ decay fungi (Hibbett and Donoghue 2001), we cannot dismiss this hypothesis.

The majority of wood decay fungi we examined in this study were heart rots (Table 1). Heart rots are relevant to woodpeckers because they decay the interior heartwood of a tree without affecting the integrity of the more exterior sapwood (Kilham 1971, Conner et al. 1994). This pattern of decay questions the relevance of a visual cue produced by a heart rot that is detectable and useful for woodpeckers. Heart rots enter the tree from outside, however, often at the site of an injury such as a broken branch or tree top (Jackson and Jackson 2004), and some Red-cockaded Woodpecker cavities are located below a branch stub where decay fungi entered the tree (Fig. 4; Conner et al. 2004). In such instances, the appearance (i.e., reflectance) of the exposed heartwood where the decay fungus enters may be altered as presented 
Exposed heartwood with reflectance possibly altered by $P$. pini or other decay fungi.

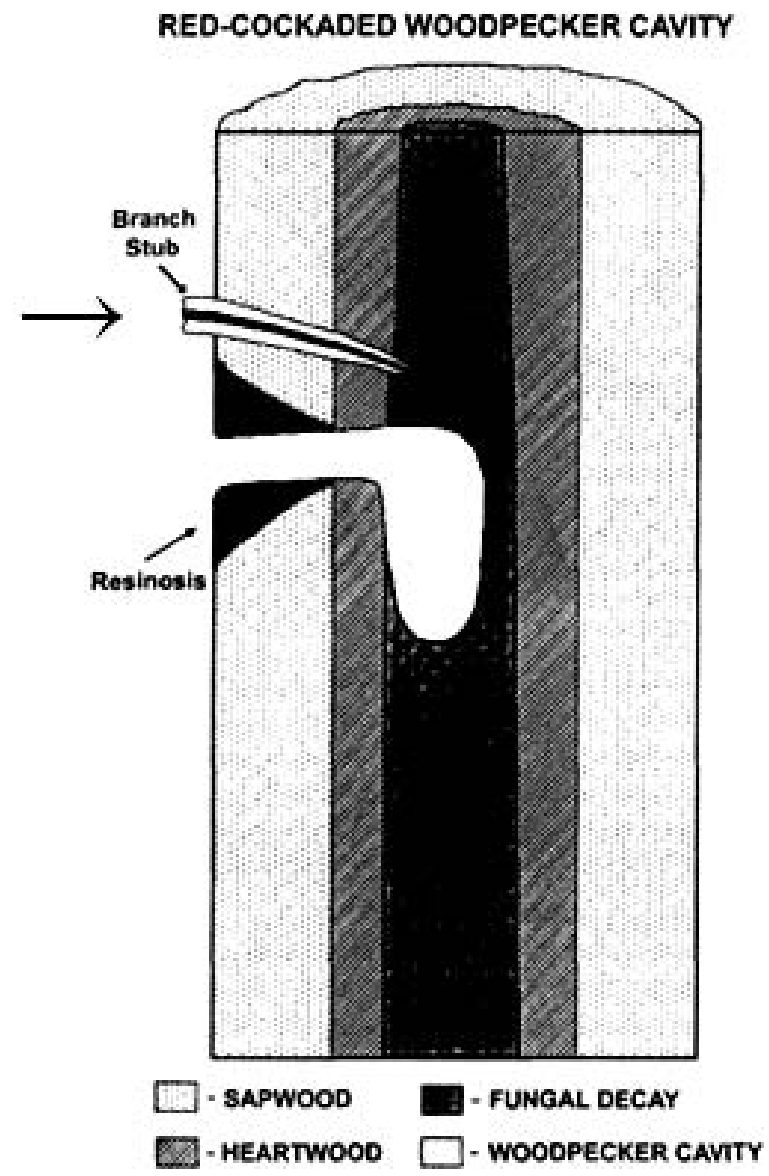

Figure 4. Diagram of a Red-cockaded Woodpecker (Leuconotopicus borealis) cavity location. Modified from figure 1 in Conner et al. (2004). This schematic provides an example of where potential visual cues produced by decay fungi (e.g., Porodadalea pini) could be found in relation to woodpecker excavations.

here. Portable spectrometers could be used in the field to investigate this hypothesis.

Many decay fungi produce species-specific combinations of volatile organic compounds (volatiles), and insects use these volatiles to locate decaying trees (Raffa and Smalley 1995). We have no data on olfactory abilities for any woodpecker species, but recent research indicates olfaction is an important sense for a wide range of avian taxa (Mihailova et al. 2014). Significant olfactory ability in woodpeckers is not a mutually exclusive theory in the detection of decayed wood substrates. Indeed, visually detectable cues could complement olfactory cues, as is often the case in plantpollinator relationships (Schiestl 2005). Because woodpeckers are known to transport fungal spores (Farris et al. 2004, Jusino et al. 2016), they could, and perhaps should, be considered to fill roles analogous to pollinators. Consideration of woodpeckers as ecological analogs to pollinators creates a number of interesting and testable hypotheses, including the existence of specialists and generalists. Evidence exists that suggests some woodpeckers may be more specialized in their ability to detect decay fungi (e.g., Yellow-bellied Sapsucker or Red-cockaded Woodpecker). Jusino et al. (2016) proposed a third hypothesis, the 'combined hypothesis,' that suggests aspects of both tree selection and bird-facilitation may play a role in woodpecker-fungal symbioses. Given our results that decayed wood may appear differently based on the decay fungus responsible, this explanation seems entirely plausible for woodpecker-fungi associations. 
Several woodpecker species are considered threatened or endangered, and the population status is recorded as declining or unknown for several others (Red List of Threatened Species; IUCN 2015). Given that woodpeckers are important components of the ecosystems they inhabit, a better understanding of woodpecker sensory ecology, and any mutualisms they participate in will likely improve conservation efforts and management strategies.

We presented evidence that decay fungi create varying substrate reflectances by species, and that such variations are likely visually detectable by woodpeckers. We stress that precise visual system parameters for any woodpecker taxa remain undescribed, and our results may be significantly influenced by changes to those parameters. Still, the idea that some woodpeckers select trees decayed by particular fungi has been supported by decades of field observations involving multiple species of woodpecker and decay fungi (e.g., Stierly 1957, Shigo and Kilham 1968, Conner et al. 1976, Jackson 1977). Although we do not present direct evidence here that woodpeckers are visually able to discriminate between wood decayed by different fungi, our results suggest this is theoretically possible. Visual cues may not be used at all or may be used in conjunction with olfactory or resonance cues. Demonstrating that such visual differences exist provides a starting point for future investigations regarding woodpecker-fungi interactions. We recommend that such future work should proceed with controlled behavioral experiments that incorporate both visual and olfactory components. Jusino et al. (2016) concluded that woodpecker-fungus relationships "may be far more complex than previously imagined." We concur with this conclusion and hope our findings will encourage further research into woodpecker sensory ecology and woodpecker-fungi mutualisms.

\section{Acknowledgments}

We thank J. Bruhn and E. Fernandez-Juricic for productive discussions at the outset of this research and $\mathrm{R}$. Maia for help navigating pavo. J. Bruhn also provided the wood wafers. We thank C. Boal, J. Powell, and 2 anonymous reviewers for comments improving earlier versions of the manuscript. Additionally, we thank J. Endler for sharing irradiance data and S. Taylor for assistance with cultivation of the fungi. Funding for this study was provided by Arkion Life Sciences, the Avian Power Line Interaction
Committee, and Critter Control, Inc. STO was partially supported by a Trans World Airlines Graduate Scholarship. We appreciate support from The Institute for Bird Populations for this published contribution number 551 .

The Missouri Cooperative Fish and Wildlife Research Unit is jointly sponsored by the Missouri Department of Conservation, the University of Missouri, the US Fish and Wildlife Service, the US Geological Survey, and the Wildlife Management Institute. Any use of trade, firm, or product names is for descriptive purposes only and does not imply endorsement by the US Government.

\section{Literature cited}

Amano HE, Eguchi K. 2002. Foraging niches of introduced Red-billed Leiothrix and native species in Japan. Ornithological Science. 1:123-131.

Aristotle. 350 BCE. The history of animals. Boston (MA): Massachusetts Institute of Technology, Internet Classics Archive. http://classics.mit.edu/

Arnett EB, Kroll AJ, Duke SD. 2010. Avian foraging and nesting use of created snags in intensively-managed forests of western Oregon, USA. Forest Ecology and Management. 260:1773-1779.

Aubry K, Raley C. 2002. The Pileated Woodpecker as a keystone habitat modifier in the Pacific Northwest. USDA Forest Service General Technical Report PSWGTR-181.

Bednarz JC, Ripper D, Radley PM. 2004. Emerging concepts and research directions in the study of cavity-nesting birds: keystone ecological processes. Condor. 106:1-4.

Blackwell BF, DeVault TL, Seamans TW, Lima SL, Baumhardt P, Fernandez-Juricic E. 2012. Exploiting avian vision with aircraft lighting to reduce bird strikes. Journal of Applied Ecology. 49:758-766.

Blanc LA, Martin K. 2012. Identifying suitable woodpecker nest trees using decay selection profiles in quaking aspen (Populus tremuloides). Forest Ecology and Management. 286:192-202.

Burns K, Shultz AJ. 2012. Widespread cryptic dichromatism and ultraviolet reflectance in the largest radiation of Neotropical songbirds: implications of accounting for avian vision in the study of plumage evolution. Auk. 129:211-221.

Conner RN, Locke BA. 1982. Fungi and Red-cockaded Woodpecker cavity trees. Wilson Bulletin. 94:64-70.

Conner RN, Miller OK Jr, Adkisson CS. 1976. Woodpecker dependence on trees infected by fungal heart rots. Wilson Bulletin. 88:575-581.

Conner RN, Rudolph DC, Saenz D, Schaefer RR. 1994. Heartwood, sapwood, and fungal decay associated with Red-cockaded Woodpecker cavity trees. Journal of Wildlife Management. 58:728-734.

Conner RN, Rudolph DC, Saenz D, Johnson RH. 2004. The Red-cockaded Woodpecker cavity tree: a very special pine. Faculty Publications, Paper 441. http:// scholarworks.sfasu.edu/forestry/441

Eaton MD. 2005. Human vision fails to distinguish widespread sexual dichromatism among sexually 
"monochromatic" birds. Proceedings of the National Academy of Sciences USA. 102:10942-10946.

Eaton MD, Lanyon SM. 2003. The ubiquity of avian ultraviolet plumage reflectance. Proceedings of the Royal Society of London, Series B. 270:1721-1726.

Endler JA. 1993. The color of light in forests and its implications. Ecological Monographs. 63:1-27.

Endler JA, Mielke PW. 2005. Comparing entire colour patterns as birds see them. Biological Journal of the Linnaean Society. 86:405-431.

Farris KL, Huss MJ, Zack S. 2004. The role of foraging woodpeckers in the decomposition of ponderosa pine snags. Condor. 106:50-59.

Harness R, Walters E. 2004. Woodpeckers and utility pole damage. In: Proceedings of the Institute of Electrical and Electronics Engineers/Industry Applications Society Rural Electric Power Conference, 2004. Paper No. 04/B3:1-7.

Hart NS. 2001. The visual ecology of avian photoreceptors. Progress in Retinal and Eye Research. 20:675-703.

Hart NS, Hunt DM. 2007. Avian visual pigments: characteristics, spectral tuning, and evolution. American Naturalist. 169:S7-S26.

Herrerra G, Zagal JC, Diaz M, Fernandez MJ, Vielma A, et al. 2008. Spectral sensitivities of photoreceptors and their role in colour discrimination in the Green-backed Firecrown Hummingbird (Sephanoides sephanoides). Journal of Comparative Physiology A. 194:785-794.

Hibbett DS, Donoghue MJ. 2001. Analysis of character correlations among wood decay mechanisms, mating systems, and substrate ranges in Homobasidiomycetes. Systematic Biology. 50:215-242.

Huss M, Bednarz JC, Juliano DM, Varland DE. 2002. The efficacy of inoculating fungi into conifer trees to promote cavity excavation by woodpeckers in managed forests in western Washington. USDA Forest Service General Technical Report. PSW-GTR-181.

Igic B, Cassey P, Grim T, Greenwood DR, Moskat C, et al. 2012. A shared chemical basis of avian host-parasite egg colour mimicry. Proceedings of the Royal Society of London, Series B. 279:1068-1076.

[IUCN] International Union for Conservation of Nature. 2015. Red List of Threatened Species. Version 2015-4; [cited 24 Mar 2016]. www.iucnredlist.org

Jackson J. 1977. Red-cockaded Woodpeckers and pine red heart disease. Auk. 94:160-163.

Jackson J, Jackson B. 2004. Ecological relationships between fungi and woodpecker cavity sites. Condor. 106:37-39.

Jusino MA, Lindner DL, Banik MT, Walters JR. 2015. Heart rot hotel: fungal communities in Red-cockaded Woodpecker excavations. Fungal Ecology. 14:33-43.

Jusino MA, Lindner DL, Banik MT, Rose KR, Walters JR. 2016. Experimental evidence of a symbiosis between Red-cockaded Woodpeckers and fungi. Proceedings of the Royal Society of London, Series B. 283:20160106.

Kemp DJ, Herberstein ME, Fleishman LJ, Endler JA, Bennett ATD, et al. 2015. An integrative framework for the appraisal of coloration in nature. American Naturalist. 185:705-724.
Kilham L. 1971. Reproductive behavior of Yellow-bellied Sapsuckers I. Preference for nesting in Fomes-infected aspens and nest hole interrelations with flying squirrels, raccoons, and other animals. Wilson Bulletin. 83:159171.

Klapstein K, Weichman FL, Bauer WN, Kenway DJ. 1989. Optical characteristics of wood stains and rot. Applied Optics. 28:4450-4452.

Maia R, Eliason CM, Bitton PP, Doucet SM, Shawkey MD. 2013. pavo: an R Package for the analysis, visualization and organization of spectral data. Methods in Ecology and Evolution. 4:906-913.

Maier EJ, Bowmaker JK. 1993. Colour vision in the passeriform bird, Leiothrix lutea: correlation of visual pigment absorbance and oil droplet transmission with spectral sensitivity. Journal of Comparative Physiology A. 172:295-301.

Martin K, Eadie J. 1999. Nest webs: a community-wide approach to the management and conservation of cavity-nesting forest birds. Forest Ecology and Management. 115:243-257.

Mihailova M, Berg M, Buchanan K, Bennett ATD. 2014. Odour-based discrimination of subspecies, species and sexes in an avian species complex, the Crimson Rosella. Animal Behaviour. 95:155-164.

Nakagawa S. 2004. A farewell to Bonferroni: the problems of low statistical power and publication bias. Behavioral Ecology. 15:1044-1045.

O’Daniels ST, Kesler DC, Mihail JD, Webb EB, Werner SJ. 2017. Functional visual sensitivity to ultraviolet wavelengths in the Pileated Woodpecker (Dryocopus pileatus), and its influence on foraging substrate selection. Physiology and Behavior. 174:144-154.

Ödeen A, Håstad O. 2003. Complex distribution of avian color vision systems revealed by sequencing the SWS1 opsin from total DNA. Molecular Biology and Evolution. 20:855-861.

Ödeen A, Håstad O, Alstrom P. 2011. Evolution of ultraviolet vision in the largest avian radiation - the passerines. BMC Evolutionary Biology. 11:313.

Olssen P, Lind O, Kelber A. 2015. Bird colour vision: behavioral thresholds reveal receptor noise. Journal of Experimental Biology. 218:184-193.

Parks CG, Bull EL, Filip GM, Gilbertson RL. 1996. Wooddecay fungi associated with woodpecker nest cavities in living western larch. Plant Disease. 80:959.

Parrish JW, Benjamin R, Smith R. 1981. Near-ultraviolet light reception in the Mallard. Auk. 98:627-628.

Parrish JW, Ptacek JA, Will KL. 1984. The detection of near-ultraviolet light by nonmigratory and migratory birds. Auk. 101:53-58.

R Core Team. 2015. R: a language and environment for statistical computing. R Foundation for Statistical Computing, Vienna, Austria. http://www.R-project.org/

Raffa KF, Smalley EB. 1995. Interaction of pre-attack and induced monoterpene concentrations in host conifer defense against bark beetle-fungal complexes. Oecologia. 102:285-295.

Renoult JP, Courtiol A, Kjellberg F. 2010. When assumptions on visual system evolution matter: nestling 
colouration and parental visual performance in birds. Journal of Evolutionary Biology. 23:220-225.

Rudolph DC, Conner RN, Schaefer RR. 1995. Redcockaded Woodpecker detection of red heart infection. In: Kulhavy DL, Robert G, Costa R, editors. Redcockaded Woodpecker: recovery, ecology, and management. Nagadoches (TX): Stephen F. Austin State University, Center for Applied Studies in Forestry; p. 338-342.

Schaefer HM, Schaefer V, Vorobyev M. 2007. Are fruit colors adapted to consumer vision and birds equally efficient in detecting colorful signals? American Naturalist. 169:S159-S169.

Schiestl FP. 2005. On the success of a swindle: pollination by deception in orchids. Naturwissenschaften. 92:255264.

Shigo A, Kilham L. 1968. Sapsuckers and Fomes igniarius var. populinus. US Department of Agriculture Forest Service, Research Note NE-84.

Steirly CC. 1957. Nesting ecology of the Red-cockaded Woodpecker in Virginia. Raven. 28:24-36.
Vorobyev M. 2003. Coloured oil droplets enhance colour discrimination. Proceedings of the Royal Society of London, Series B. 270:1255-1261.

Vorobyev M, Osorio D. 1998. Receptor noise as a determinant of colour thresholds. Proceedings of the Royal Society of London, Series B. 265:351-358.

Vorobyev MD, Osorio D, Bennett ATD, Marshall NJ, Cuthill IC. 1998. Tetrachromacy, oil droplets and bird plumage colours. Journal of Comparative Physiology A. 183:621-633.

Winternitz BL, Cahn H. 1983. Nestholes in live and dead aspen. In: Davis JW, Goodwin GA, Ockenfels RA, technical coordinators. Snag habitat management: proceedings of the symposium. US Department of Agriculture Forest Service, General Technical Report RM-99; p. 102-106.

Zahner V, Sikora L, Pasinelli G. 2012. Heart rot as a key factor for cavity tree selection in the Black Woodpecker. Forest Ecology and Management. 271:98-103. 